\title{
Islamic Fundamentalism in Nigeria and the Church's Response
}

\author{
Dr. Ekundayo, Lawrence Olabode \\ Department of Religion and African Culture, Faculty of Arts, Adekunle Ajasin University, Akungba- Akoko \\ Ondo State, Nigeria, West Africa
}

\begin{abstract}
The paper has examined Islamic fundamentalism and the Church's response in Nigeria. The research problem of this paper is the deliberate attempt of the Muslim fanatics to stunt the growth of Christianity. Due to this problem, it is the aims of this paper to investigate the activities of Islamic fundamentalists, its effects on the Church and the role of the Church in the face of the persecution. The paper presents the Biblical background of Christian persecution, the history and the principles of Islamic fundamentalism in Nigeria. The paper, having used historical approach, showed that the activities of Islamic fundamentalists are both religious and political. The paper contributes to knowledge by revealing the motive of Islamic fundamentalists. The paper, therefore, recommends that: the secularity of Nigerian constitution must be respected to enable freedom of religion. The Muslim leaders must be active in correcting the heresies of the fundamentalists since they also kill Muslim faithful in Nigeria.
\end{abstract}

Keywords: Biblical, Church, Fundamentalism, Muslim, Nigeria.

\section{INTRODUCTION}

Fundamentalism was first used in 1920 by Curtis Lee Laws to denounce the modernist party in the Northern Baptist Convention in USA. ${ }^{1}$ Originally, the fundamentalists have the objective of maintaining the doctrinal interpretations of the Bible and the tradition of the Christian. ${ }^{2}$ They guarded the church from Darwinism, secularism and liberal theology. ${ }^{3}$ Fundamentalism differs from conservatism, traditionalism, classicism, and orthodoxism. While conservatism harmlessly preserves the tenets of their belief, traditionalism aggressively preserves their traditions without going outside their religious bodies. Also, the orthodoxy and classicism protect their beliefs and religious values passionately with high level of civility. ${ }^{4}$ Fundamentalism has also been identified as the major cause of Church proliferation in Nigeria.

In Nigeria, the word fundamentalism began to be applied to religious Islamic extremists since the Maitatsine riot in Kano, Nigeria in 1980. In the recent time, fundamentalism becomes widened to include the activities of Muslim suicide bombers, Islamic terrorist activities and all sorts of religious extremist behaviors. Islamic fundamentalism has never become an effective factor of positive socioreligious and economic change in the society; because their activities have always been anti-human. Fundamentalists in any religion or society are essentially an opposition movement. They are confrontational and believe strongly that they are the only one that is right; and that those who do not agree with them must be put to the sword. "This makes them unwilling and indeed incapable of engaging in any form of dialogue that might lead them to revise their positions."

Though, Fundamentalist terrorism is not exclusive to Islam; the Jews and Christians have used terrorist acts to draw attention to themselves and to force their beliefs and opinions on the society.

\footnotetext{
${ }^{1}$ Sinclair, B. Ferguson (Ed.), New Dictionary of Theology, England: Inter-Varsity Press, 1988, P. 266.

2 James, Hughes (Ed.), the Larousse Desk References, New York: Larousse King Fisher Chambers Inc., 2001, P. 29.

${ }^{3}$ Chernow, B.A and Vallasi, G.A. (Ed.), Columbia Encyclopedia, Fifth Edition, Columbia: Columbia University Press, 1975, P. 1026.

${ }^{4}$ Paul, Barry Clarke and Andrew Linzey (Ed.), Dictionary of Ethics, Theology and Society, Datix International Ltd., 1997, P. 388.

${ }^{5}$ John, Bowden (Ed.), Encyclopedia of Christianity, USA: Oxford University Press, 2005, P. 481.
} 
However, this paper will concentrate on Islamic fundamentalist terrorism and its effect on the Church and the society.

\section{BIBLICAL BACKGROUND OF CHRISTIANS’ PERSECUTION}

Violence is naturally familiar to humankind and it is part of human characters that makes them to rebel against God. ${ }^{6}$ Hence, there will be no major solution to persecution and Christian suffering until mankind reach some understandings of who they are, what the purpose of creation was and what happens after death. Until these questions are settled Christians will continue to suffer. ${ }^{7}$

The early Church considered Jesus as the archetypal martyr who was persecuted on account of his teachings. ${ }^{8}$ After Jesus, the first apostle to be killed was Stephen. The early Christian believed that it was presumptuous to seek death, but it was cowardly and faithless to refuse it on account of persecution. ${ }^{9}$ Consequently, the Church's persecution from Nero in 64 AD to Constantine in the year 313 AD witnessed numerous Christians' casualties. Though, the actual numbers of Christians who died during these 129 years were not known. Eusebius in his record wrote that multitude of people wandered in the wilderness and mountains, and some were killed by the wild animals, starvation and hunger. Alexandria affirmed that many Christians were torn asunder by the heathen in cities and villages. Dionysius also indicated that Christians were destroyed in large numbers but could not give the accurate numbers. To have relative ideas of the early Church's persecution, this paper will consider the persecution of Christians under various emperors:

Nero Persecution: The first Persecution was started by Nero from the misunderstanding of Christian's concepts. At that time, there were no Church buildings; Christians met in houses of brethren to share 'Love Feast' and this was practiced under closed doors. They were, therefore, accused of sexual immorality and cannibalism arising from the statement: 'Take and eat it, this is my body; drink it all of you, this is my blood.' Again, in July 64 AD, there was a serious inferno in the city of Rome and for 6 days the fire burned unabated. Nero was the suspect in connection with the fire. But to exonerate himself "Nero fixed the guilt on a class of people, commonly called Christians." ${ }^{10}$ Nero dressed Christians in animals' skins and threw them to the wild animals in his garden in full glare of the populace. Foster wrote that:

Nero persecution did not spread beyond the city of

Rome. It was not carried out for religious reasons, but was to satisfy one man's (Nero's) cruelty. Large numbers of Christians were killed in the capital, only 35 years after the death of Christ. Men had been put to death just because they were Christians. ${ }^{11}$

Domitian Persecution: In AD 86, Domitian ignited the second Christians' persecution. $\mathrm{He}$ condemned Christians as atheists who were haters of humanity. This was because Christians refused to join the army and to serve in the government. Also, Christians considered it as sacrilegious to go to the public theatre to worship emperor or state gods. This refusal made them to incur the wrath of Domitian. ${ }^{12}$ Hence, Christians were dragged to the amphitheatre centre where they were made to face wild lions, bears and panthers.

Ignatius, the Bishop of Antioch in 107 was a victim of Domitian persecution. When Ignatius was brought to the amphitheatre centre to face wild animals in Rome he wrote to the Churches in Rome saying:

\footnotetext{
${ }^{6}$ Roben, Keeley, the Lion Handbook of Christian Belief, Australia: Lion Publishing, 1983, P. 294.

${ }^{7}$ Roben, the Lion Handbook, P. 294.

${ }^{8}$ Sinclair, B. Ferguson (Ed.), New Dictionary, P. 412.

${ }^{9}$ Harry, R. Boer, A Short History of the Early Church, Ibadan: Daystar Press, 1976, P. 33.

${ }^{10}$ John, Foster, the First Advanced Church Historyl: AD29-500, London: SPCK, 1987, P. 68.

${ }^{11}$ John, the First Advanced Church, 69.

${ }^{12}$ Harry, A Short History, P. 46.
} 
I know what is best for me. Now I am beginning to be a disciple. Let fire come, or a cross, or facing of beasts, and crushing of my whole body. Only let me get to Jesus Christ, Permit me to be a copy of the suffering of my God. ${ }^{13}$

Decius' Persecution: The year AD 250 witnessed an empire-wide persecution of the Christians. By the year 248, the empire had declined from its former great glory because of so much sedition. Six Emperors had been assassinated in quick succession. People had abandoned paganism and state religion (emperor worship) to embrace Christianity. The Church became formidable and independent in the empire.
Disputes between Christians were brought to their own Bishops, never before non-Christian magistrates. Christian charities helped not only their own poor, but others besides. If a Christian had to travel to distant places, he carried letters of introduction, and was at once among friends. ${ }^{14}$

This Christian practice made Decius to accuse Christians of being 'Imperium in imperio' meaning that the Church was operating a state within a state. Hence, Decius decided to destroy the Church institution so as to give way to the state. Consequently, Decius promulgated an edict of compulsory sacrifice to the Roman idols and the Emperor. The magistrates were to supervise and ensure the compliance of everyone in the empire. A certificate of obedience (Libellus) was to be issued to everyone after the sacrifice must have been done.

Numerous Christians across the empire were persecuted for their disobedience to sacrifice to Roman gods. ${ }^{15}$ Church leaders were not left out of this persecution. While leaders like Pope Fabian, Alexander of Jerusalem, Babylas of Antioch were killed; Cyprian who was t he Bishop of Carthage escaped death by hiding.

Valerian Persecution: When Valerian became emperor he split the empire into two and delegated the authority of the West to his son, Gallienus, as the Caesar; while he took charge of the administration of the East. In 257, he ordered all Christian ministers to make sacrifices to the Roman gods or face execution. Again, he commanded Christian senators, knights and all Christian officials in Roman government to worship Roman gods or lose their positions if they should refuse. During this time Cyprian, bishop of Carthage, who had earlier escaped from Decius Persecution, was executed. Pope Sixtus II, the bishop of Rome, Lawrence of Rome and notable deacons in the empire were executed.
Valerian's policy was to execute bishops and senior clergy, and thus leave the Church leaderless. But the empire was disturbed by both barbarian and Persian invaders, and Valerian's plans were not fully carried out. ${ }^{16}$

Emperor Gallienus Reign of Peace: He reigned with his father from 253 to 260. But by 260, after the death of his father, he began to reign alone until 268. The greatest achievements of his administration were his military reforms and the policy of Christian toleration in the empire. He promulgated an edict in 261 that it is unlawful to persecute Christians. This makes the Church to flourish and many Christians occupied high positions in the empire. Hence, Christians enjoyed peace for a period of 40 years. This period was referred to as the "Little Peace of the Church." The peaceful period was terminated by Diocletian in 284 .

Diocletianic Persecution: when Diocletian became emperor he revoked the edict of toleration made by Gallienus; and in $303 \mathrm{AD}$ he instructed that all Churches should be destroyed and Christian religion should be abrogated.

\footnotetext{
${ }^{13}$ John, The First Advanced Church, P. 72.

${ }^{14}$ John, The First Advanced Church, P. 74.

15 Wikipedia, Decian Persecution, Retrieved from: http://www. en.m.wikipedia.org. last modified 26 April, 2015.

${ }^{16}$ John, The First Advanced Church, P. 76.
} 
In Phrygia, in AD 305, a Church was put on fire with the entire congregation inside during worship. In the same manner, the Christians in Nicomedia were carried to the sea and all were pushed into the sea. Some Christians were however committed to forced labor; and some were maimed by either burning the tendons of their legs or by gouging one of their eyes. ${ }^{17}$ The end of Christian's persecution in the early Church came with the emergence of Constantine as the first Christian emperor. Constantine went into the war with a Christian sign of cross which was formed from two Greek alphabets: $\chi$ and $\rho$ representing the first two letters of $\chi \rho \imath \sigma \tau o \varsigma$ (Christ). The Constantine Victory at the battle of the Milvian Bridge in 312 changed the Christians' experience from persecution to state favored religion. Christianity became the foremost religion of the entire Roman Empire. This was a great development in the early Church. Constantine was baptized before his death, and after his death he was instituted as a saint because of his role in promoting Christianity.

\section{THE PRINCIPLES OF ISLAMIC FUNDAMENTALISM}

The Islamic fundamentalist groups are extreme religious sects that pursue socio-political and religious agenda using Islam as the basis. Their basic ideology is to make Nigeria an Islamic nation. They have deep aversion for education, democracy and western culture. Boko haram fundamentalist leader, Shekau Abubakar, reaffirmed his conviction to erode democracy from Nigeria when he said:

I will never allow democracy to thrive. The concept of government of the people by the people for the people will never be possible and will never exist. Democracy shall be replaced only by the government of Allah, from Allah and for Allah. ${ }^{18}$

Christianity is their first target which must be replaced with Islam. The Islamic fundamentalists consider Sharia implementation as a primary project rather than a religious corpus. They believe that women are mere objects of comfort for men. Hence, they oppose women education and indoctrinate that children must marry at the age of 7 years. They also teach that it is forbidden for women to engage in social activities.

The Islamic fundamentalists are self opinionated, for this reason they avoid dialogues so that their concepts will not be influenced. They consider themselves as reformists and believe that the societal problems emanate from secular abuses. They maintain that Islamic traditionalists and the liberals are not true Muslims and they take them as apostates. Their agitation is to have an Islamic state where shari'a, hadith and Sunnah will be fully operated with no respect for human rights. They have no regards for freedom of religion, gender equality, freedom of speech and freedom of association; and to exist, one must belong to them. They affirm the concept of proselytism and harsh penalties for their enemies because to them Quran is inerrant and must be accepted as the only moral codes of conduct for religious and political practices. Part of their ideology is that all forms of nationalism and maxims must be destroyed to allow the concept of Allah's sovereignty to thrive. To them atheism is a sacrilegious crime; humanity must be completely religious and Islam is the only way to access God.

In their doctrine, a true Muslim must be willing to kill or get killed to rid the society of paganism; and their holiness is in the ability to take blood in serving Allah. They profess an authoritarian Islam in which humanity must be coerced to accept all the traditions of the Prophet Muhammad and they believe that Islam must wield absolute power that will make it superior to the state. In other words, the state must be placed under Islamic government which is a government of shari'a and hadith. For this to be achieved, "every extant form of authority must be replaced with the rule by Islamic jurist."19

Islamic fundamentalists believe that the actual solution to the societal decadence is to adhere to the principles of Islam. They are earthnocentric with extremist passion to overthrow the world through terrorism. They are not only a problem to Christianity but also a threat to local, national and global peace and security. In summary, they are the Nazists, the Fascists and the Communists of the contemporary society who have constituted themselves as men of violence for the men of Words and dialogue.

\footnotetext{
${ }^{17}$ Wikipedia, Decian Persecution, Retrieved from: http://www. en.m.wikipedia.org.

${ }^{18}$ The Nation, Nigeria Newspaper, Thursday 26 September, 2013, 21.

19 Martin, Kramer, Fundamentalist Islam at Large: the drive for Power, Retrieves from: www.meforum.org. Modified 12 April, 2015
} 


\title{
THE HISTORY OF ISLAMIC FUNDAMENTALISM IN NIGERIA
}

The two major religions in Nigeria are Christianity and Islam. These religions have always been on the throats of each other and their relationship is precipitated on mistrust, malice, suspicion and hatred, particularly in the northern part of Nigeria. However, both religions had been managing the disaffection until Maitatsine riot in Kano in December 1980. The riot was an intra Muslim crisis championed by the Maitatsine fundamentalists to purify Islam from idolatry and syncretism.

Within two weeks, the Maitatsine had killed about 5,000 people. Though, a large number of the casualties were Muslims, scores of Christians were also killed. Many Churches, Christian Schools and businesses were destroyed. By October 1982, the Maitatsine fundamentalists had taken their battle to the cities of Maiduguri, Rigassa and Kaduna; their focus was on both Christians and Muslims. By February 1984, the riot had been taken to Jimeta, Yola and Gombe; and in all these cities about 1200 Christians were killed and many were forced to renounce their faith to embrace Islam.

The Maitatsine riot had no sooner subsided than the riot of the Muslim Students' Society of Nigeria began in 1985, also in Kano. The riot was a Muslims' protest against the building of a new St. George's Anglican Church which was said to be too close to a Mosque in Fagge district of Kano. Despite the fact that the old Church building had been there since 1930 before the Mosque in question was built in 1970. The fundamentalist Muslim youth put the Church to sword and 564 Christians lost their lives. $^{20}$

The Christians in Kano experienced another gruesome persecution due to Reinhard Bonnke revival activities in October 1991. The Muslim fundamentalists, suspecting that Reinhard would convert Muslims to Christianity like he had done in some other towns, mobilized at the emir's palace in Kano from where they spread out to the entire town in search of Christians; and within four days over 500 people had been massacred. Many Christians were displaced to army barracks and police stations. Anyone who dressed in English was instantly put to sword. Christians' shops, houses, schools, farm plantations and 22 Churches were reduced to ashes.

December 29, 1994 witnessed another bloodbath in Kano. This began with Mrs. Akaluka who was accused of using Quran's pages as toilet paper in a public toilet in Kano-Market. Gideon Akaluka, the husband of the woman and a Christian was beheaded for defending his wife and his head was thrust into a pole and was carried round the city of Kano in pomp and pageantry. However, the emir of Kano condemned the dastardly act, but the condemnation did not go down well with the Muslim extremists who immediately took to the streets and started killing Christians. After one week over 300 Christians were sent to their untimely graves

The year 1997 became another experience of Christians' persecution in Kafanchan Kaduna state. The cause of this persecution was the message preached by Rev. Abubakar Bako who was a Muslim convert. Abubakar cited Quran's passages to support the divinity of Jesus Christ. This was seen as an affront by the Muslim fundamentalists who under the ledership of Umaru Aisha mobilized Izala Muslim group. Also, all Muslim students of Kafanchan College of Education were drawn out to hunt for Christians with weapons and kegs of petrol to burn houses and Churches in the town.

At the end of one week, 458 Christians were killed; while 31 Churches were reduced to ashes. Invariably, the fundamentalists extended their Christians' hunt to Zaria, Katsina and Wusasa.

\begin{abstract}
Almost every Christian in Wusasa was molested. They were asked to recite the Muslim creed. Some were bitten and left for dead, naked on the street. Mrs. Denejo Ibrahim and Mrs. Naandeti were among the unlucky victms, while some were ruffled, cut and maimed. ${ }^{21}$
\end{abstract}

After this, came the 1998 Zango-Kataf Christians' persecution. It was a riot against the decision of Baban Ayok a Christian chairman of the Zango-Kataf local government. Baban had instructed that the town's market be moved to a new location. The Muslims traders saw the relocation order as a political victimization. Hence, the Muslim extremists came out on Sunday May 17, 1998 and attacked Christians in Zango-Kataf and in allover Kaduna metropolis; and very many Church leaders were murdered in cold blood.

\footnotetext{
${ }^{20}$ Jan, H. Boer, Nigeria's Decades of Blood 1980-2002, vol. 1, Jos: Honey City Press, 2003, P. 40.

${ }^{21}$ Jan, H. Nigeria's Decades of Blood, P. 113
} 


\begin{abstract}
Katung, the Zaria CAN secretary, was stabbed in the stomach and died. They butchered Bije an elderly Baptist Pastor. They gouged his eyes and cut through his mouth to his chin. They also burnt down his Church, his residence and all the properties in it, including two vehicles. Dunijo, an ECWA Pastor, was equally mangled in his house. They also cut him deeply across the mouth. Revd. Tacio was killed at home and dragged out to the street where his body laid for 24 hours. Killed along with him were at least twenty five members of his Church. ${ }^{22}$
\end{abstract}

By the year 2000, Islamic fundamentalism took a new dimension when the Governor of Zamfara state in Nigeria adopted the practice of shari'a to impose Islamic court system on both Christians and Muslim in the state. The Christians took a resolution not to submit themselves to shari'a law. Consequently, a riot broke out and the Islamic extremists swooped down on the Christians and were forcing them to recite some appointed verses of Quran. Those who refused or failed were immediately slaughtered. In this persecution, over 2500 Christians were killed. Obasanjo in his presidential visit to Zamfara described the loss of lives as the worst in Nigerian experience of religious riot. But little did he know that the worst is yet to come with Boko Haram.

Today, the rate at which Islamic fundamentalists kill innocent people in Nigeria is mind boggling and is worse than the persecution of the French Huguenot and other Christian minorities in Europe, the Chinese cultural revolution, the two wars in Vietnam instigated by the French and Americans respectively, the Apartheid system in South Africa, the systematic and deliberate extirpation of the Native Indians and other indigenes in South America by the Spaniard, the Northern Island Debacle and the two world wars. The international community must do everything possible to assist Nigeria to stop this carnage against humanity.

\title{
CHURCH'S RESPONSE TO ISLAMIC TERRORISM
}

The major problem of the Nigerian Church is the threat of Islamic fundamentalists. The Christian, more than ever before, risk their goods, their freedom, positions and their lives to practice Christianity. Christians' fellowships, worship and Church services are considered as abomination by the Boko Haram; and to dress as Christians is to call for an untimely death. In every village the Church is the first institution of attack. This situation, has forced the Church to come to term with the reality that "religion and terrorism are a powerful mix and when religion empowers terrorism, then, terrorism apparently has no limits and acknowledges no boundaries." ${ }^{23}$ Hence, the Church has reacted proactively to terrorism in the following ways:

First, Church's inauguration of anti-terrorist groups: The Church, having realized that one of the best approaches to overcome terrorism is to adopt a counter terrorist measure which includes: The establishment of a Pressure group to lobby government against Church victimization, the Church also organize the youth to serve as vigilantes in Christian's towns and communities to complement the efforts of the law enforcement agencies. In most cases, in North, the youth constitute themselves as militia to guard the Church during the Church's services and worships. They also conduct security search and screenings on everyone coming for Church's programs. Many suicide bombers have been detected and arrested through the church's vigilante activities.

The second approach of the Church is the adoption of communication strategy. The church often organizes press conferences to condemn the dastardly acts of terrorism against the Church. The Church organizes retreats, Conventions and synods on terrorism and communiqués are issued and published to condemn the Islamic fundamentalist attack on the Church. The Church also volunteers regular information to the security agencies; through intelligent information terrorists are put on surveillance.

Another Church's response to terrorism is the strategy of Church planting. Islamic fundamentalists attack the Church to create an atmosphere of fear to discourage Muslims' conversions to Christianity and to prevent the Church from spreading. But, in reacting to this, the Church has embarked upon

\footnotetext{
22 Jan, H. Nigeria's Decades of Blood, P. 118

${ }^{23}$ Veitch, James, “Terrorism and Religion,” Stimulus, vol. 10, nol, February 2002, P. 26.
} 
aggressive evangelism. For instance, the Anglican Church of Nigeria has established 23 missionary Dioceses in the insurgent endemic northern region of Nigeria. All the Bishops, clergy and the Churches in these missionary Dioceses are being financed and coordinated by the Dioceses in the Southern Nigeria. This has mitigated the effect of terrorism on the Church and the Church has continued to spread in defiant to Islamic fundamentalist persecution.

The Church has also reacted to Islamic terrorism is the exhibition of the power of unity. The more the Churches in Nigeria are terrorized the more they come together as one body, one faith, one spirit under one Lord and one God. Nigerian Churches (denominations) now speak with one voice under the umbrella of the Christians' Association of Nigeria (CAN). Whatever happens to a Church becomes an issue to all denominations. CAN has organized several rallies to protest against Islamic policies considered inimical to the Church. When Shari'a was introduced in Zamfara state in 2000, Christians were mobilized by the CAN; and the Church took to the streets in hundreds of thousands to denounce shari'a imposition on them. In short, the Christian have used the power of unity to mitigate the effect of terrorism on the Church.

\section{RECOMMENDATIONS}

Now that this work has shown the effects of the Islamic fundamentalist terrorism on the Nigerian people, we recommend as follows:

i. That government and law enforcement agencies must not encourage extra-judicial killings of the fundamentalists, because the more they kill them the more they are likely to have sympathy among their brotherhood. Hence, those arrested should be thoroughly investigated to expose their terrorist strategies and sponsors.

ii. Government should put in place a rehabilitation program to integrate the disillusioned fundamentalists back to the norms and values of the society. This may include special training that will provide jobs for them.

iii. Since Islamic extremists also kill Muslims, it is necessary for the Ulamas, the Muslim religious leaders and scholars to be active in correcting the heresies and wrong interpretations of Quran by the fundamentalists. The various Quran's concepts that have been subjected to misinterpretations by the extremists must be re-contextualized. Muslims should also organize counseling units in the Mosques to dissuade terrorist's sympathizers from supporting terrorist acts in order to break the circle of violence in the religion.

iv. It is equally necessary for government to organize counseling units in all the tertiary institutions to dissuade the Islamic youth from having interest in terrorism; this will also bring the Muslim deviants to repentance and remorse.

v. Government must encourage the military, police and other law enforcement agencies to undertake refresher courses to acquire modern knowledge, intelligence and expertise in the field of terrorism. This will make them more effective in stemming the upsurge of terrorism.

vi. Government must employ intelligence gathering and technique with precision. It is important to investigate the sources of funding of the fundamentalists. Where they get their arms and ammunitions and who fund their supplies, where did they procure their vehicles and equipment and who are paying for these services. Unless government deploys energy and resources to block these sources of funding, the quest to rid the Nigerian nation of Islamic fundamentalists may remain illusory.

vii. There should be international collaboration and cooperation of the neighboring countries such as Niger, Chad, Cameroon and other countries within the West African Sub-region in term of sub-regional task forces and sharing of intelligence and information with Nigerian government. Cooperation must also be elicited at the level of the Commonwealth and the United Nations. The international cooperation will make it easy to trace and prevent the movement of fundamentalists, their finances and supplies of equipment.

viii. Another necessary measure is for Nigerian government to establish mechanisms for periodic reviews and strategic monitoring of compliance regime with international counter-terrorism measures. These categories of measures are important in that terrorist methods and tactics are constantly changing with implications that counter-terrorism measures must also respond to these changes as they unfold. These responses cannot be effective and efficient in the absence 
Dr. Ekundayo \& Lawrence Olabode "Islamic Fundamentalism in Nigeria and the Church's Response"

of periodic reviews and strategic monitoring. These would ensure that Nigeria is in tune with international standards and best practices in dealing with the surge of fundamentalist terrorism.

ix. The United States government should review Nigeria's status regarding the application of the Leahy Law to enable the country access appropriate modern weapons. The Leahy Law is a US human rights law that prohibits the US Departments of State and Department of Defence from providing military assistance to foreign military units that violate human rights with impunity. Unfortunately, the blanket application of the Leahy Law against Nigerian soldiers on the allegation of human rights violations has denied the country access to modern weapons to curb insurgency.

x. Nigerian government needs to adopt the use of Information Communication Technology (ICT) to tackle insecurity by equipping the toll gates, sea and air ports and borders with 'fire gates' that will screen vehicles, detect lethal objects, including acid, dangerous chemicals, guns, explosives, arms and ammunition. Again, there is no criminal data base in Nigeria and whenever a serial offender is arrested; it is a new case since there is no criminal data base. Every agency is arresting criminals, interrogating them and let them go after writing a statement. Each Police station, Military, Nigeria Security and Civil Defence Corps (NSDC), Nigeria Customs Service (NCS) and the Nigeria Immigration Service (NIS) should have their own criminal data base; and it should all be interlinked. It shall be part of the duty of the ICT professionals to equip Armed Forces with the right knowledge and also inform the Presidency about the latest technologies that are available to detect crimes.

xi. Above all, both Christianity and Islam must begin to promote family values. Parents must be educated to take full responsibility of fending for their children. Islamic religion, in particular, must discourage a situation where in the Northern Nigeria; a parent may give birth to over 15 children only to send them out as Almajiri to beg for alms. These children grow up to hate life, humanity, elitist society and government for injustice. The neglect they suffered makes it easy for them to commit crimes because they have never enjoyed love.

\section{CONCLUSION}

Abubakar Shekau of Boko Haram could be compared with Adolf Hitler of Nazism who launched operation final solution on the Jewish nation. This operation saw the extermination of six million Jews, including the Blacks, Jehovah Witnesses, gypsies, the disabled and others he considered racially inferior; as they were taken to various death camps scattered across Poland, Austria and Germany for slaughter. In the end, the Allied Forces closed-in on him in his Berlin bunker where he committed suicide in May $23^{\text {rd }} 1945$. This means that evil cannot continue to prevail over good; and that those who perpetrate atrocities and criminalities will never end well.

The case of Shekau bears the same similitude of the Hitler, Just as Hitler had no reason for the bloodletting that rocked Europe so Shekau has no reason for his genocide against humanity. In the long, no matter how painful the gruesome activities of Shekau, his war against humanity will fail.

\section{REFERENCES}

[1] Chernow, B.A and Vallasi, G.A. (Ed.), Columbia Encyclopedia, Fifth Edition, Columbia: Columbia University Press, 1975, P. 1026.

[2] Harry, R. Boer, A Short History of the Early Church, Ibadan: Daystar Press, 1976, P. 33.

[3] James, Hughes (Ed.), The Larousse Desk References, New York: Larousse King Fisher Chambers Inc., 2001, P. 29.

[4] John, Bowden (Ed.), Encyclopedia of Christianity, USA: Oxford University Press, 2005, P. 481.

[5] John, Foster, The First Advanced Church Historyl: AD29-500, London: SPCK, 1987, P. 68.

[6] Jan, H. Boer, Nigeria's Decades of Blood 1980-2002, vol. 1, Jos: Honey City Press, 2003, P. 40.

[7] Martin, Kramer, Fundamentalist Islam at Large: the drive for Power, Retrieves from: www.meforum.org. Modified 12 April, 2015

[8] Paul, Barry Clarke and Andrew Linzey (Ed.), Dictionary of Ethics, Theology and Society, Datix International Ltd., 1997, P. 388.

[9] Roben, Keeley, The Lion Handbook of Christian Belief, Australia: Lion Publishing, 1983, P. 294. 
Dr. Ekundayo \& Lawrence Olabode "Islamic Fundamentalism in Nigeria and the Church's Response"

[10] Sinclair, B. Ferguson (Ed.), New Dictionary of Theology, England: Inter-Varsity Press, 1988, P. 266.

[11] The Nation, Nigeria Newspaper, Thursday 26 September, 2013, 21.

[12] Veitch, James, "Terrorism and Religion," Stimulus, vol. 10, nol, February 2002, P. 26.

[13] Wikipedia, Decian Persecution, Retrieved from: http://www. en.m.wikipedia.org. last modified 26 April, 2015. 